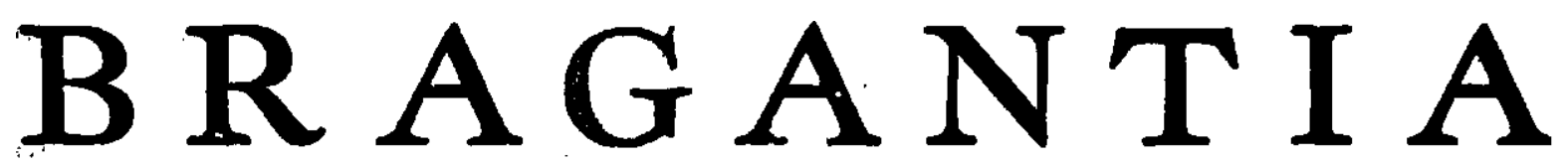

Boletim Técnico do Instituto Agronômico do Estado de São Paulo \begin{tabular}{lll}
\hline \hline Vol. 14 & Campinas, novembro de 1955 & N. \\
\hline \hline
\end{tabular}

\title{
MELHORAMENTO DA VIDEIRA (*)
}

\author{
Josf Ribeiro Almeida Santos Neto \\ Engenheiro agrônomo, Seção de Viticultura, Instituto Agronômico
}

\section{RESUMO}

Os primeiros trabalhos sôbre o melhoramento da videira no Brasil datam de 1895 e se devem a Pereira Barreto e seus colaboradores.

Entre 1930 e 1940, em Amparo, Paulino Recch, Nicolau Martorano e Pedro Araujo, dedicaram-se ao melhoramento da videira obtendo espécimes de real valor.

A partir de 1943, no Instituto Agronômico, a Seção de Viticultura vem desenvolvendo um programa traçado para prover a nossa viticultura de abundante material melhorado para múltiplas finalidades.

Cogita-se da obtenção de variedades novas para porta-enxertos, para mesa, vinho, suco não fermentado e passa.

Essas variedades devem apresentar características de adaptação e acomodação ao nosso meio ambiente ; resistência às moléstias e pragas, e ao apodrecimento ocasionado pelas chuvas ; boas características especificas para mesa, vinho e suco não fermentado (1 a 18).

Para execução do programa foi utilizado o material existente nas coleções do Instituto Agronômico, e importado novo material das Américas do Norte e Central.

Dos capítulos mais importantes, um que está sendo atacado é o da produção de uvas de mesa isentas de sementes, ou apirenas.

Igual importância tem 0 referente às diferentes combinações.com as variedades tropicais, principalmente Vitis gigas e V. tiliæfolia.

Os resultados até agora obtidos são animadores : o Instituto Agronômico já dispõe de novos porta-enxertos em estudo, novas variedades de mesa com características de grande valor, numerosas variedades para produção de bons vinhos, bem como outras que, combinadas em diferentes proporçбes, produzem excelente suco não fermentado.

Os trabalhos prosseguem e, não sendo interrompidos, poderão trazer reais vantagens \& viticultura nacional.

\section{1 - INTRODUÇÃO}

Em São Paulo a videira é cultivada desde os tempos coloniais, tendo sido introduzida pelos portuguêses, que a usavam para o consumo de mesa e para a produção de vinho. As plantações eram formadas por castas européias.

Com o decorrer dos anos foram introduzidas no Brasil as videiras americanas, dotadas de características vegetativas que melhor se adaptam às nossas condições de ambiente. Entretanto são destituídas das excelentes qualidades de sabor e aroma, inerentes às finas castas européias.

(") Trabalho apresentado ao II Congresso Panamericano de Agronomia, realizado em Piracicaba e Båo Pedro, de 29 de março a 6 de abril de 1954.

Recebido para publicacăo em 17 de junho de 1955. 
As americanas prosperaram entre nós, já pelo motivo mencionado, como também devido, principalmente, à sua resistência às principais moléstias que atacam a videira no nosso ambiente, e à produção mais volumosa, embora de.qualidade inferior, vindo a predominar nas plantações brasileiras em mais de $90 \%$. Deduz-se, assim, que o grosso da uva de mesa que se consome, bem como do vinho que se produz, não prima pela excelência de sua qualidade.

Um olhar lançado. para o futuro desta imensidade brasileira, onde, com o tempo, a população forçosamente será triplicada ou quadruplicada, nos impele a meditar e agir no sentido de preparar, para as gerações vindouras, novas variedades, dotadas das qualidades das castas americanas adaptadas ao nosso meio, e que tenham ao mesmo tempo o aroma, o sabor e outras finas qualidades das castas européias. Este trabalho vem sendo executado pelo Instituto Agronômico, por intermédio da Seção de Viticultura, já há dez anos, com paciência, tenacidade, e sem alarde.

Entretanto, entre nós, quem primeiro se dedicou ao ạsunto, dando os primeiros passos com a finalidade de obter novas variedades, foi Pereira Barreto, em 1895, coadjuvado por Campos da $\mathrm{Pa}, \mathrm{z}$, Henrique Vaz, Arnaldo Vieira, Francisco Camargo, José Barreto e Cincinato (15). No ano de 1897 foram efetuadas 43 combinações diferentes entre diversas castas americanas e européias. Grande incremento tomou a viticultura em São Paulo com os trabalhos e as iniciativas de Pereira Barreto.

Mais tarde, na cidade de Amparo, entre os anos de 1930 e 1940, Paulino Recch, Nicolau Martorano e Pedro Araujo cuidaram da obtenção de novas variedades de videira melhoradas, obtendo cêrca de duas centenas de plantas, entre as quais algumas de real valor.

Estava, assim, aberto o caminho para a criação de castas brasileiras, destinadas a marcar o início de uma nova viticultura entre nós, que viesse a ser, no futuro, um ramo de exploração agrícola altamente lucrativo e portador de bem-estar para todos os que a êle se dedicassem.

Em 1943, ao serem iniciados os trabalhos de melhoramento da videira na Seção de Viticultura do Instituto Agronômico, em Campinas, três considerações foram feitas preliminarmente : $1 .^{\mathrm{A}}$ ) quanto ao clima; $2 .^{\mathrm{a}}$ ) quanto à biologia da planta; $\left.3 .^{a}\right)$ quanto ao que se considera, realmente, uma boa variedade.

\section{1 - O CLIMA}

Fator importante no crescimento e adaptação das plantas, para a videira é sub-tropical, semi-árido, com inverno frio e úmido, verão quente e sêco. Comparando o clima de São Paulo ao de muitas outras regiões do Brasil, verifica-se que estamos em condições diametralmente opostas, com inverno ameno e sêco, e verão quente e úmido. Em tais condições, uma vinífera está sujeita a um desequilíbrio, pela ausência de um período de frio acentuado que promova a fase de dormência, pela susceptibilidade a moléstias num ambiente de temperatura elevada e excessiva precipitação pluvial, como ainda pela falta de luminosidade na situação em que nos achamos, com dias curtos, o que influi na execução plena das suas funç̃es fisiológicas. 
Em tal clima acomodam-se melhor as castas americanas, principalmente as da Flórida.

\section{2 - A BIOLOGIA}

A biologia da videira consiste nos diferentes estágios de seu ciclo vegetativo :

1..$^{\circ}$ brotação das gemas e aparecimento dos ramos novos;

2..$^{\circ}$ florescimento ;

3. $\left.{ }^{\circ}\right)$ desenvolvimento dos cachos até a maturação dạs bagas;

4..$^{\circ}$ amadurecimento do lenho dos ramos e queda das fôlhas, completando-se, então, o período de crescimento;

5..$^{\circ}$ repouso hibernal até a primavera seguinte, para recomeçar o mesmo ciclo.

\section{3 - UMA BOA VARIEDADE}

Deve preencher os seguintes requisitos, uma boa variedade de videira :

1. $\left.{ }^{\circ}\right)$ resistência às moléstias que lhe são mais prejudiciais, e cujo combate seja mais difícil e dispendioso ;

2. ${ }^{\circ}$ ) apresentar adaptação às condições de clima da região, para que sua cultura possa expandir-se em vastas áreas;

3. ) ser produtiva, fornecendo boas colheitas com regularidade;

4. $\left.{ }^{\circ}\right)$ seus frutos devem atingir completa maturação, e se apresentar livres de apodrecimento e de outros estragos, ser de boa qualidade, com alto teor de açúcar e com acidez relativamente baixa, bem como ter os demais elementos constitutivos em equilíbrio harmônico;

5..$^{\circ}$ preencher satisfatòriamente os diferentes estágios do ciclo biológico característico da videira.

Dentro destas considerações básicas foi organizado um programa de melhoramento da videira, cuja finalidade é a obtenção de novas variedades para mesa, vinho, suco não fermentado, passa e porta-enxertos, as quais, sobretudo, sejam estáveis sob o ponto de vista econômico, isto é, forneçam produçóes abundantes e de boa qualidade ano após ano, e dêm lucros compensadores, até mesmo quando tenham de competir com produto semelhante de outras regióes do país ou do estrangeiro. Um bom produto, bem padronizado, a um prêço acessível, certamente estará fadado a ter enorme consumo e a constituir uma indústria em bases sólidas e duradouras entre nós.

\section{2 - METODO}

O método por nós empregado foi o da hibridação, que em viticultura vem sendo usado há 125 anos, com extraordinárias vantagens.

Não apresenta grandes dificuldades na técnica de sua execução, mas exige, de quem trabalha, muita dedicação, paciência, ânimo, e até uma dóse de resignação para suportar os insucessos certos a que todos estão sujeitos nas diferentes fases em que as operações são executadas. 


\section{1 - FLOR DA VIDEIRA}

A inflorescência da videira é do tipo cacho composto, também chamada panícula.

A flor, hermafrodita na grande maioria das variedades cultivadas, é provida de cinco estames férteis (inseridos na base da flor pelos filamentos), ovário, estilo e estigma, cobertos pela corola de cinco pétalas unidas entre si pelo ápice. A abertura dà flor se dá pela base, e a corola, ao se destacar, se apresenta intata e com as extremidades das pétalas recurvadas para fora, assemelhando-se a um chapéu. Os estames se distendem, mantendo-se erectos (figura $1-F$ ).
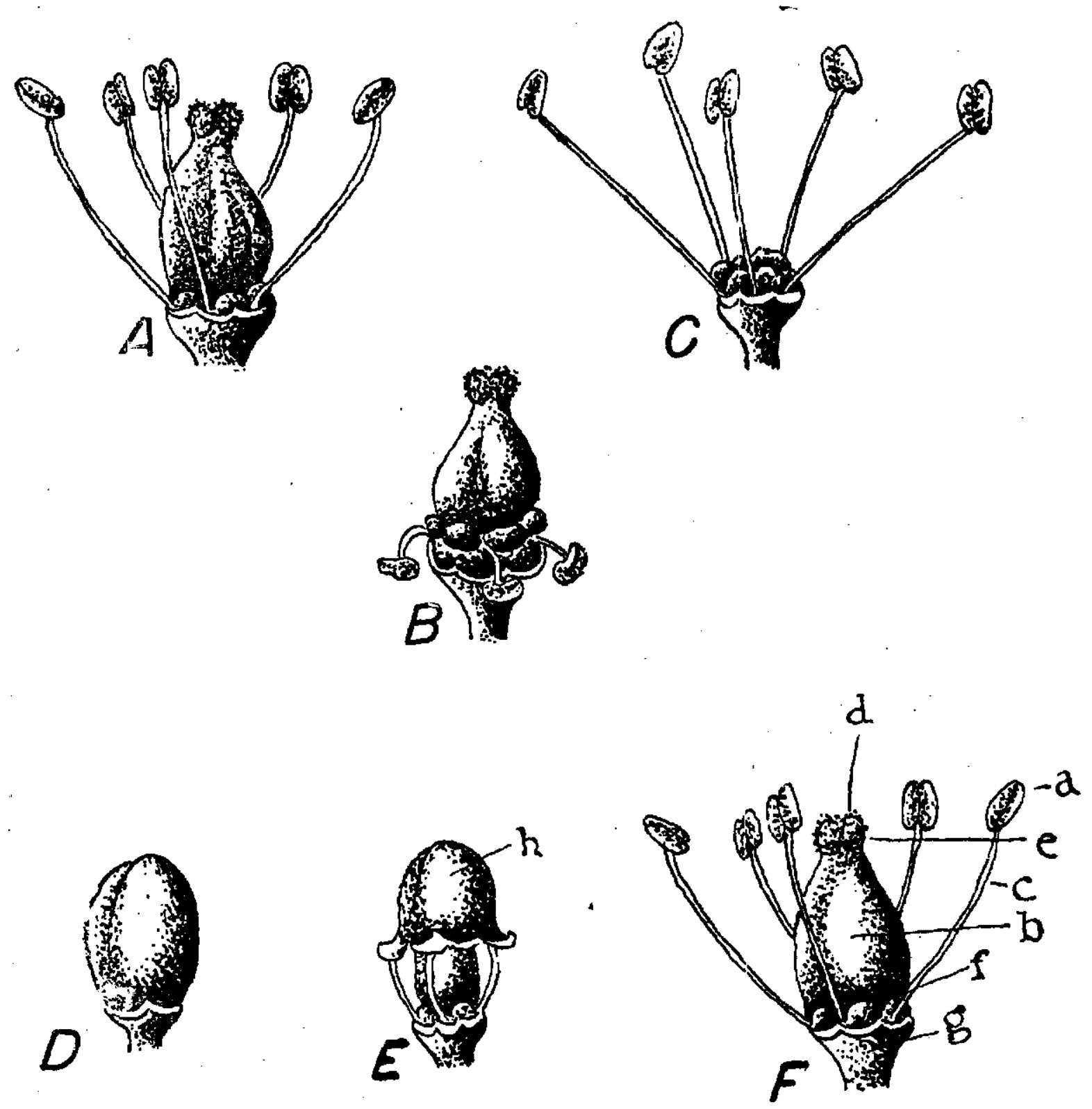

Fradra 1. - Representação esquemática da flor da videira. $A$ - flor hermafrodita; $B$ - feminina ; $C$ - masculina ; $D, E, F$ - fases da abertura da flor, podendo-re notar: a - antera; b - cvário; $\mathbf{c}-$ filkmento; d - estigma; e estilo; f - nectário; $\mathbf{g}$ - cálice; $\mathbf{h}$ - corola. 


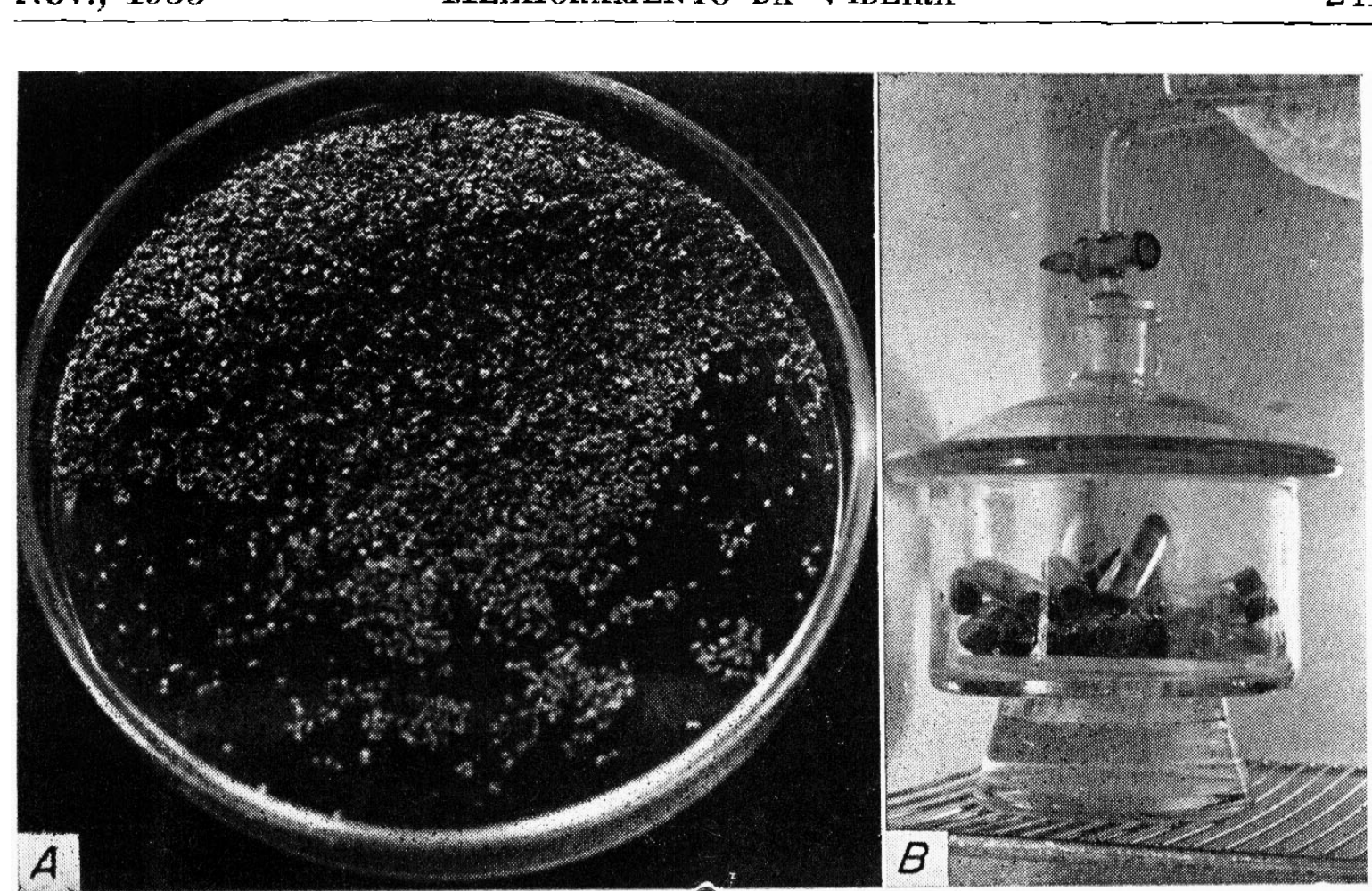

Figura 2. - $A$ - anteras de flôr de videira, recém colhidas e conservadas em caixa de Petri; $B$ - conservação de grãos de pólen em ambiente de temperatura e umidade relativa controladas.

Em algumas variec.ades os estames se apresentam defeituosamente desenvolvidos, recurvarios para baixo, dificultando e até mesmo impossibilitando a polinização do estigma, sendo consideradas como flôres femininas ou pistiladas (figura $1-B$ ).

Em outras variedades, notadamente entre as videiras silvestres, dá-se a atrofia dos brgãos femininos, tendo-se, pois, flôres masculinas ou estaminadas (figura $1-C$ ).

Geralmente êsses tipos de flôres conduzem à esterilidade parcial, no primeiro caso, e total, no segundo.

\section{2 - EMASCULAÇÃO}

Estabelecidos quais sejam os progenitores femininos, deve-se dar preferência às melhores plantas, nas quais se escolhem as inflorescências a serem emasculadas. Temos sido melhor sucedidos trabalhando com inflorescências bem desenvolvidas, em que as primeiras flôres começam a abrir. Estas devem ser eliminadas totalmente, só se utilizando as flôres bem fechadas (estampa $1-A)\left({ }^{1}\right)$. Em seguida, com auxílio de uma pinça metálica, reta, leve, e de pontas finas, cuidadosamente se removem de cada flor a corola e os estames, evitando traumatizar o estigma (estampa $1-B$ ). Terminada esta operação 'estampa $2-A$ ), a inflorescência deve ser coberta com saquinho de papel vegetal impermeável, para proteção e isolamento (estampa $2-B$ ).

(1) A utilizagáo de inflorescências ainda novas, ou com desenvolvimento muito adiantado, nos tem conduzido i perda de trabalho e completo insucesso. 


\section{3 - COLHEITA DO POLEN}

A colheita do pólen e feita retirando-se das plentas correspondentes aos progenitores masculinos, as inflorescências apresentando já algumas flôres abertas, as quais são totalmente eliminadas, e em seguida, pela emasculação por meio de uma pinça metálica, recolhendo-se as anteras numa cápsula de Petri, onde permanecem durante cêrca de 12 horas, para uma leve desidratação e prevenção contra o môfo (figura $2-A$ ).

A conservação do pólen se faz em pequenos vidros cilíndricos, com uma das extremidades abertas, depositados em dessecador contendo solução de ácido sulfúrico a $25 \%$, mantido num refrigerador à temperatura do $5^{\circ} \mathrm{C}$ (figura $2-B$ ).

Desta forma conseguimos conservar, durante vários meses, o pólen de algumas variedades. $O$ pólen da Dutchess e de seu descendente I.A.C. 181, não se conservou além de 40 dias ; o da 493-D 10 só se conservou durante um mês ; o pólen da Vitis tiliæfolia e da $V$. gigas, no fim de três semanas não mais apresentava vitalidade.

Parece um tanto variável, pelo menos entre nós e nas condições em que estamos executando os nossos trabalhos, o espaço de tempo durante o qual o pólen se conserva viável. Por essa razão temos procurado utilizá-lo durante os 15 dias subseqüentes à sua coleta, pela segurança com que contamos, nêsse período, para o bom êxito dos trabalhos.

Observamos também, durante os nossos trabalhos, a dificuldade de se conseguirem resultados satisfatórios, sob diferentes aspectos, com o pólen de algumas variedades, notadamente a Dutchess e a 493-D 10, parecendo haver como que uma insensibilidade de certas vinfferas ao recebê-lo em seus estigmas. Parece que, de fato, há certas incompatibilidades entre algumas castas, o que, às vêzzes, impede a execução integral de um programa de trabalho, obrigando a introduzir modificações.

\section{4 - POLINIZAÇĀ()}

Procuramos efetuar a polinização da maneira que nos pareceu mais prática, rápida e segura. Utilizamos os próprios vidjinhos em que se achava conservado o pólen, fechando-os com uma rôlha de tamanho adequado, com a designação do progenitor masculino na parte superior. Para executar a operação retira-se, cuidadosamente, o saquinho de papel vegetal que está envolvendo a inflorescência emasculada do progenitor feminino ; agita-se o vidrinho fortemente para que o pólen fique aderente à superfície inferior da rôlha e, delicadamente, sôbre o estigma de cada flor, deposita-se o pólen encostando a rôlha de leve e com muita atenção para que tôdas as flôres fiquem polinizadas (estampa $3-A$ ).

Se o pólen for conservado em refrigerador, será de tôda conveniência, antes de empregá-lo, fazer com que readquira a temperatura ambiente, para que haja igualdade de condições, o que favorece a polinização.

Não temos obtido bons resultados efetuando a polinização no mesmo dia em que as flôres são emasculadas. E de tôda a vantagem efetuar a operação no segundo ou terceiro dia, quando os estigmas se acham receptivos, 
apresentando-se umidecidos por uma secreção viscosa. E nêsse estado que temos conseguido os melhores resultados. A hora de se efetuar a operação parece exercer alguma influência, pois temos sido melhor sucedidos ao executá-la até às 11 da manhã, quando a temperatura não está muito elevada.

A operação deve ser repetida duas a três vêzes, nos dias seguintes, para assegurar maior quantidade de sementes. Mantém-se a inflorescência protegida com saquinho de papel vegetal, coloca-se uma etiquêta com as designaçōes dos progenitores feminino e masculino e a data em que se efetuou a operação (estampa $3-B$ ). Por fim, prende-se a extremidade do saquinho a uma fôlha da planta, com o auxílio de uma presilha metálica, para evitar que o vento quebre o pedúnculo da inflorescência e ocasione a sua perda.

$\mathrm{E}$ indispensável fazer observações periódicas nos cachos, para se certificar da maneira como se desenvolvem, mudar os saquinhos por outros maiores, verificar as etiquêtas e efetuar a colheita depois de bem maduros.

Preferimos manter os cachos protegidos até o dia da colheita, para evitar estragos de insetos, pássaros ou granizo.

\section{5 - SEMENTE E SEMENTEIRA}

Após a colheita dos cachos, que pode ser efetuada depois da sua maturação fisiológica, as sementes são retiradas dos frutos, lavadas, postas para secar ao ar, tratadas com Uspulum sêco e conservadas em saquinhos de papel contendo os dizeres referentes aos cruzamentos, número de sementes e data da colheita.

Antes da semeadura temos submetido a totalidade das sementes a um tratamento preliminar, mantendo-as, durante um mês, estratificadas em areia e musgo umedecidos, em cápsulas de Petri, à temperatura de $5^{\circ} \mathrm{C}$ num refrigerador.

A semeadura é feita em canteiros de terra, no interior de estufa e ripado, em fileiras espaçadas de $0,20 \mathrm{~m}$ entre si, nas quais se dispõem as sementes a $0,05 \mathrm{~m}$ umas das outras e $0,02-0,03 \mathrm{~m}$ de profundidade, suficientemente irrigadas (figura $3-A$ ).

Em 10-15 dias tem início a germinação, que é muito variável, porcentualmente, nas diversas combinaçōes efetuadas, prolongando-se por dois, e, em certos casos, três mêses.

A medida que as plantinhas vão se desenvolvendo, é necessário que lhes sejam dispensados todos os cuidados e práticas que favoreçam o seu bom crescimento (figura $3-B$ ), durante o primeiro ano, a fim de que forneçam material que possa ser utilizado para enxertia na época apropriada.

Tôdas as plantas são marcadas com o número correspondente ao cruzamento, seguido de outro referente ao que lhe cabe dentro do cruzamento, separado por um traço, - antecedidos do prefixo I.A.C.

\section{6 - CAMPO DE HIBRIDOS}

Está localizado em um lote de três hectares de terreno, na Seção de Viticultura, na Fazenda Santa Elisa, o qual todos os anos é parcialmente valetado, estercado, adubado, e plantado com estacas do porta-enxêrto 

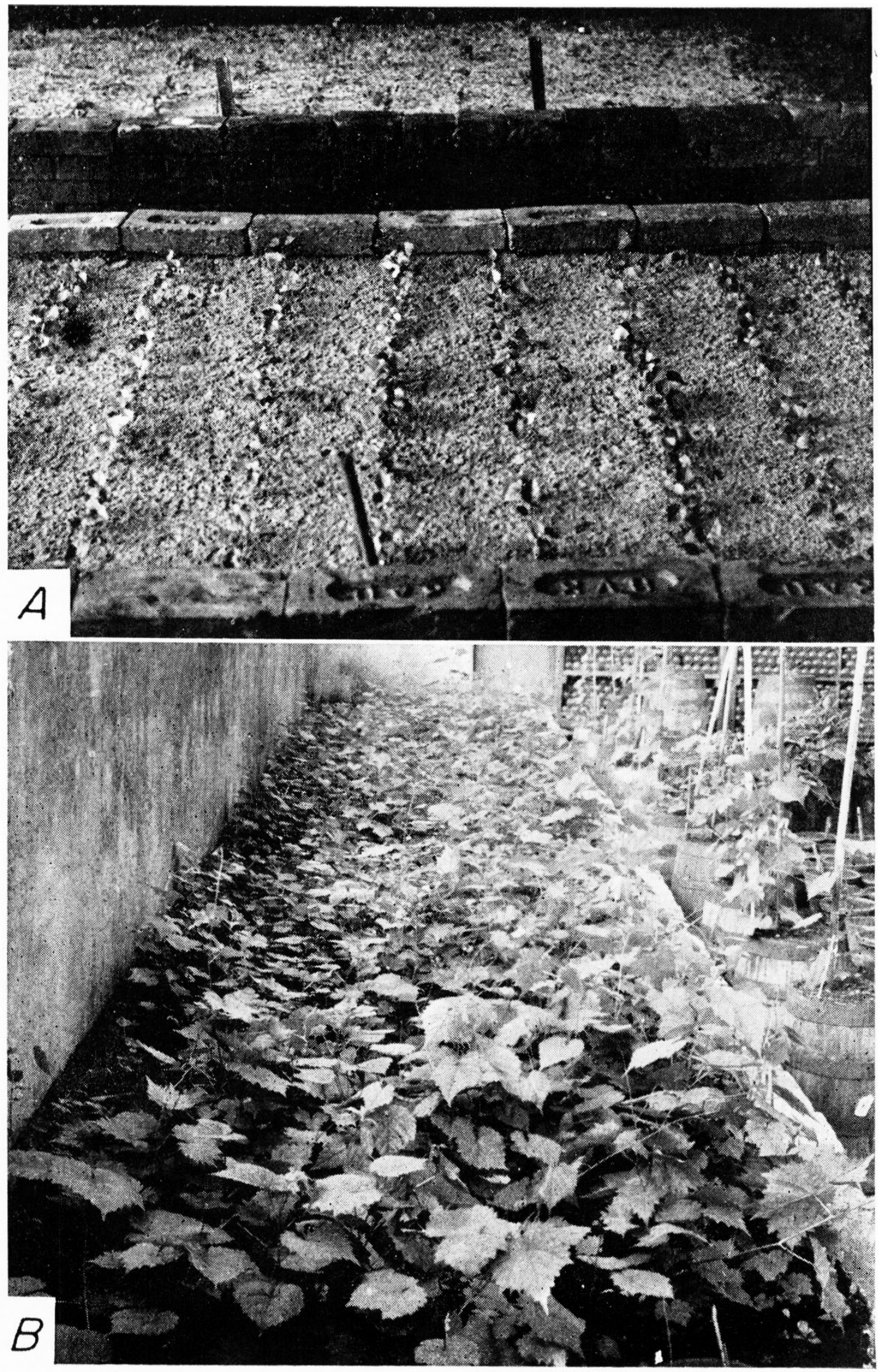

Figura 3. - $A$ - "seedlings" recém germinados, em canteiros de terra na estufa; $B$ "seedlings" com cêrca de um ano de idade. 
Golia, no espaçamento de $2 \mathrm{~m} \times 0,75 \mathrm{~m}$, para atender às nossas necessidades de enxertia de híbridos novos criados na Seção de Viticultura, anualmente. Atualmente existem cêrca de 15.000 plantas, correspondentes a 3.000 novos híbridos, que estão sendo estudados, registrando-se em fichas apropriadas tôdas as anotações a êles referentes e com as quais se torna possível, depois de quatro anos de observações, de estudos analíticos e enológicos, seguidos de provas de degustação, fazer um juízo preliminar de seus predicados. Selecionam-se, então, aquêles cujas características para determinada finalidade forem satisfatórias, depois de julgadas com rigor, para, com maior número de plantas, formarem-se os lotes semi-comerciais.

\subsection{1 - LOTES SEMI-COMERCIAIS}

Tais lotes se acham situados na Seção de Viticultura, na Fazenda Santa Elisa, contando cada um com 70 a 100 plantas de cada variedade nova selecionada, enxertadas sôbre cinco diferentes porta-enxertos, das quais se obtém produção em quantidade mais volumosa. Assim se torna possível efetuar estudos e observações de acôrdo com a finalidade a que cada uma se destina, e obter resultados concludentes que servirão de base para a formação de novos vinhedos, o que já vem sendo feito, não só em diversas localidades de São Paulo, mas ainda em Caldas, Minas Gerais, em Campo Largo, Paraná, em Bento Gonçalves e Flôres da Cunha, Rio Grande do Sul.

\section{7 - APRECIAÇÃO DOS RESULTADOS}

Os resultados obtidos até hoje provêm das muitas e repetidas observações feitas periòdicamente, a partir dos canteiros, do campo de híbridos, até à última prova de laboratório. Muitas são as modificações por que passam as novas variedades com o decorrer dos anos, às vêzes para melhor, outras para pior, em gráu variável. Raramente as primeiras impressões, ou os primeiros julgamentos se tornam definitivos.

As plantas tôdas, de acôrdo com sua numeração, são fichadas uniformemente, registrando-se as observações conseguidas no campo e no laboratório. Temos procurado efetuar o julgamento com todo o rigor, em equipe, eliminando personalismos, preconceitos, agindo dentro de um critério rígido, para que os crros sejam em número reduzido, e o material que venha a ser selecionado scja satisfatório sob múltiplos aspectos, e, por fim, útil à coletividade. Para melhor atingir a nossa finalidade, temos recorrido aos especialistas nacionais e estrangeiros, cuja opinião e conceitos nos têm sido muito proveitosos e facilitado o nosso trabalho.

\section{3 - MATERIAIS}

\section{1 - CONSIDERAÇÕES GERAIS}

E de grande vantagem, nos trabalhos dessa naturesa, dispor de farto material, dotado de características as mais variadas, o que sobremodo facilita a escolha e a separação das variedades, de acôrdo com o fim que es tem em vista. 
Lançamos mão das coleçðes ampelográficas do Instituto Agronômico situadas em Campinas, onde trabalhamos, e nas suas Estações Experimentais.

Para atingir as finalidades do que foi programado, ficou estabelecido o critério de que um dos progenitores devia preencher satisfatòriamente os requisitos de uma boa variedade, com exceção de "boa qualidade dos frutos, alto teor de açúcar, acidez baixa, e equilíbrio harmônico entre os demais elementos constitutivos". Reunimos num agrupamento as espécies americanas, vários híbridos com parentesco próximo des castas americanas, híbridos Seibel de frutos graúdos, híbridos Couderc, híbridos Malègue, todos há muitos anos cultivados em nosso meio. $\mathrm{O}$ outro progenitor devia apresentar frutos de alta qualidade, acidez baixa e equilíbrio harmônico entre os seus elementos constitutivos, ficando em segundo plano os demais requisitos. Nêste agrupamento incluem-se as castas européias e híbridos entre castas européias.

\subsection{1 - UVAS PARA MESA}

Uma boa variedade de uva para mesa deve cupresentar cachos médios ou grandes, regulares, e soltos ; bagas graúdas, iguais, de formato característico, bem aderentes ao pedicelo, que deve ser longo e forte ; película resistente, delgada, pruinosa, bem colorida; polpa carnosa, de sabor delicado, doce, simples, ou aromático ; sementes pequenas, tenras, em número reduzido ou de todo inexistentes; devem ser suficientemente resistentes para se conservarem na planta durante algum tempo, aguentar os transportes a longas distâncias, o armazenamento e a conservação frigorficica.

Em seu conjunto, devem os cachos impressionar favoravelmente pela beleza, porque, primeiramente, "êles são comidos pelos olhos", o que até certo ponto é verdadeiro. Todavia, não basta satisfazer aos olhos, é necessário satisfazer também ao paladar.

A obtenção de "boas variedades" para mesa não é muito fácil, e muito esfôrço tem sido feito nêsse sentido, com resultados satisfatórios, principalmente na Itália e na América do Norte. Tais variedades, entretanto, têm tido sucesso sòmente em regiôes favoráveis ao cultivo das viniferas. Em outras regiōes são necessários numerosos tratamentos e um prêço de venda da fruta muito elevado para que seja possivel manter econômicamente uma cultura, às vêzes bem limitada.

O nosso problema básico consiste em obter novas variedades para mesa, que sejam resistentes à antracnose, ao míldio e ao oídio, e que se desenvolvam bem no nosso ambiente, fornecendo colheitas satisfatórias de uva de mesa de boa qualidade.

Relativamente a "boa qualidade" devemos procurar conseguir novas variedades que apresentem frutos de alta palatabilidade, perfeita maturação, elevado teor de açúcar, baixa acidez, a fim de melhor satisfazer ao paladar brasileiro, cujas tendências são acentuadas para frutas tão doces quanto possivel, sem nenhum traço de acidez.

Além disso é notória entre nós a grande preferência pelas uvas de sabor e aroma "moscatel", característica peculiar de certas vinfferas, pelas quais se pagam elevados prêços. 
Variedades portadoras de tais caracteres, e que possam ser cultivadas vantajosamente entre nós, dentro de condiçőes econômicas e naturais, ainda não possuímos em plantações comerciais.

Nos nossos trabalhos já foram conseguidas muitas novas variedades moscatéis, dentre elas algumas que consideramos "boas variedades para mesa" e que, a partir de 1954, começaram a ser utilizadas para a formação de vinhedos comerciais, com grande possibilidade de fornecerem produção que venha melhorar qualitativa e quantitativamente 0 abastecimento de nosso mercado consumidor.

Quanto ao mercado de uva de mesa, é muito importante dilatar o período de seu abastecimento, para o consumidor contar com fruta fresca durante maior espaço de tempo. Para atender a tal finalidade estabelecemos o critério de lançar mão dos progenitores de acôrdo com o seu período vegetativo, grupando-os, pela época de maturação, em precoces, de maturação normal ou média e tardia.

E provável que, com novas e boas variedades que amadureçam em épocas diferentes e suficientemente espaçadas, seja possivel aprovisionar de fruta o nosso mercado e atender às necessidades dos consumidores durante cêrca de seis meses, o que, certamente, representará, do ponto de vista econômico, uma vantagem de grande repercussão para o país.

Outro assunto levado em grande consideração foi a possibilidade de se conseguirem, para as nossas especialíssimas condiçzes de ambiente, novas variedades de mesa desprovidas de sementes, ou apirenas, o que não é fácil, pela diminuta resistência de tais frutos às chuvas, que ocasionam estragos e o seu apodrecimento quase total entre nós.

Grande é o número de especialistas no assunto, em vários países, que empregam ingentes esforços e muita dedicação em programas organizados especialmente com $o$ intuito de obter boas variedades de uva de mesa apirenas, tendo-se conseguido algumas de elevados méritos, das quais temos lançado mão fartamente nos nossos trabalhos e com sucesso inicial algo animador.

Um tal tipo de uva representa o ideal no que concerne à uva para mesa, principalmente se ela apresentar, com as demais características, bagas grandes e providas de aroma e sabor moscatel, particularidades essas que, aliadas a adaptação ao nosso ambiente e resistência às moléstias, virão constituir o que se poderá designar de "perfeição".

Os nossos trabalhos nêsse sentido têm sido intensos, e parece que estamos em meio do caminho, já tendo em cultura e em produção os progenitores moscatel e apireno, dotados de adaptação e resistência necessárias.

\subsection{2 - UVAS PARA VINHO}

Nas uvas para vinho não há necessildade dos mesmos requisitos das uvas para mesa, relativamente à beleza dos cachos, tamanho das bagas, ausência de sementes, etc. Se o vinho que se deseja obter está na dependéncia da uva, ela, quando madura, deve conter um elevado teor de açúcar, acidez relatívamente baixa, e os demais elementos constituintes em equilíbrio harmônico, não apresentar cheiro e sabor "foxado" ou herbáceo ou outros inde- 
sejáveis, para que, quando transformada em vinho, dispense a adição de corretivos de qualquer natureza e forneça um produto dotado de sabor, côr, cheiro, corpo, etc., que, em conjunto, possa ser considerado de boa qualidade, satisfazendo às exigêncilas dos cultivadores de uva, dos que preparam os vinhos, e dos consumidores.

Pensamos poder afirmar que, dentre as numerosas novas variedades que já temos em nossos lotes de observação, aproximadamente uma dezena das possuidoras de sabor franco, e outra dezena de moscatéis, entre brancas e tintas, podem ser consideradas "boas variedades", pela qualidade do produto que fornecem, pelas suas características analíticas, pela sua produção e pelo seu comportamento no campo em relação a cutras variedades.

\subsection{3 - UVAS PARA SUCO NÃO FERMENTADO}

O suco de uva não fermentado em nosso clima está tendo grande aceitação e ganhando popularidade.

Entre nós são largamente empregadas, no preparo industrial do suco de uva, as variedades americanas Isabel e Concord.

O nosso trabalho está orientado no sentido de obter novas variedades portadoras de sabor agradável ao paladar, de côr acentuada e viva, de acidez baixa, riqueza de açúcar e equilíbrio entre os seus elementos constitutivos, e esperamos em futuro não longínquo lograr resultados satisfatórios.

E condição básica, que as variedades destinadas ao preparo do suco de uva possuam a particularidade de conservar os seus cachos por longo tempo na planta, sem sofrerem estragos ou apodrecimento, a fim de que atinjam sua perfeita maturação e adquiram tôdas as características necessárias à obtenção de um produto de alta qualidade.

\subsection{4 - UVAS PARA PASSA}

Entre nós não existe, presentemente, organixação para a produção industrial de passa ; além disso, as nossas condições ambientes não se apresentam favoráveis à produção de passa ao natural, mas sim por meios artificiais.

Para passa devem ser preferidas uvas sem semente, de côr branca, de bagas graúdas, uniformes, de sabor moscatel, e que atinjam a sua completa maturação sem apresentar estragos nos frutos.

Como foi exposto atrás, quando tratamos de uvas de mesa apirenas, estamos trabalhando intensamente com o fito de conseguir novas variedades dotadas de tais características, as quais, num futuro langínquo, possivelmente, venham a fornecer matéria prima para a indústria brasileira de passa, em bases racionais e econômicas.

\subsection{5 - VARIEDADES PARA PORTA-ENXERTOS}

Está generalizado hoje em dia o uso de porta-enxêrtos com resistência à filoxera, no estabelecimento de um vinhedo. Um bom porta-enxêrto deve possuir adaptação ao terreno, facilidade de enraizarnento, afinidade com o enxêrto, bom desenvolvimento vegetativo, longevidade grande, resistência a pragas e moléstias. 
Para as nossas condiçóes mesológicas, além de resistência a pragas e moléstias, as características mais importantes nos porta-enxêrtos são a adaptação ao terreno, - assunto bastante complexo, pelas diferentes classes de terreno existentes entre nós, e pela maneira como se comportam os diferentes porta-enxêrtos nos nossos terrenos, - e a afinidade com o enxêrto, isto $e$, a harmonia que deve existir entre as duas plantas reunidas pela enxertia, tanto sob o ponto de vista anatômico como fisiológico.

Numerosos especialistas têm se dedicado a tais estudos, mas sem chegar a resultados concludentes definitivos e seguros.

De nossos trabalhos obtivemos um tipo complexo muito promissor, dotado de vigor, facilidade de enraizamento, resistência, e que se acha em cultura, enxertado com diversas novas variedades, com sucesso inicial.

\section{2 - MATERIAIS BÁSICOS UTILIZADOS NOS CRUZAMENTOS}

Para metodizar o trabalho, as diversas variedades de videira usadas nas hibridações foram reunidas em grupos, de conformidade com o fim que se tinha em mirra e as suas características básicas que fundamentam o nosso programa de melhoramento.

\section{GRUPO}

DUTCHESS

NIĀGARA BRANCA

NIÁGARA ROSADA

HIGHLAND

GOLDEN MUSCAT

SEIBEL 7.226

SEIBEL 10.076
SEIBEL 11.342

SEIBEL 13.053

SEIBEL 14.583

V. TILIAEFOLIA

V. GIGAS

V. SHUTTLEWORTHII

V. RUFO TOMENTOSA

V. SIMPSONI

II GRUPO

PÉROLA DE CSABA

MOSCATEL DE HAMBURGO

GOLDEN QUEEN

GROS COLMAN

MOSCATEL ROSADA

ALFONSE LAVALÊ

MOSCATEL CATARATO CERLETTI

MOSCATEL DE ALEXANDRIA

ROZAKI ROSADO

ITĀLIA

MOSCATEL DE TERRACINA

PERLONA

SULTANINA BRANCA

PERLETTE

JUMBO

DIAMANTE NEGRO

SAN MARTINO

PIROVANO 57

SEIBEL 7.053

SEIBEL 7.162

SEIBEL 8.712

SEIBEL 8.745

SEIBEL 10.096

III GRUPO

COUDERC 16

COUDERC 17

MALEGUE 16.478

PIGNOLETA

NORTON'S VIRGINIA

JACQUEZ

IV GRUPO

ROT GEWURZ TRAMINER

ALVARALHÃO

BARBERA

CABERNET SAUVIGNON

RUBY CABERNET

MERLOT

SYRAH'

MOSCATEL FRONTIGNAN

MOSCATEL DR. HOGG

MOSCATEL DE CANELLI 


\section{GRUPO}

GOLIA

TRAVIU

R $\times$ R 101-14

CHAMPINI

As combinações se fizeram entre o primeiro e o segundo grupos com o fito de procurar obter novas variedades de uva de mesa. Entre o terceiro e o quarto grupos, para obtenção de novas variedades de uva para vinho. Também se fizeram combinaçס̃es entre o segundo e o terceiro grupos com variadas finalidades. Para a obtenção de novos porta-enxêrtos as combinações foram feitas entre as variedades tropicais do primeiro e as do quinto grupo.

Atualmente estão sendo feitas auto-fecundações das inflorescências das novas variedades já selecionadas, para obtenção de $F_{2}$, retro-cruzamentos, e outras combinaçóes entre novas variedades com as que se acham incluídas nos quatro grupos, de acôrdo com a finalidade era vista.

Até fins de 1953, o número de combinaçбes efetuadas atingiu o tóal de 532, cada qual com número muito variável de plantas.

\subsection{1 - VIDEIRAS TROPICAIS}

Sendo o Brasil um imenso país dotado de climas os mais variados, desde o temperado, nos Estados sulinos, ao tropical, nos Estados situados ao norte, é de grande interêsse econômico que a viticultura seja estabelecida e difundida nas regiões de clima quente em bases sólidas e racionais.

E uma realidade a existência de videiras que vegetam e produzem frutos normalmente em regiões tropicais, apresentando inteira resistência às moléstias criptogâmicas e aos ataques de insetos. Seus frutos não satisfazem aos requisitos para mesa ou para vinho, pelo seu pequeno tamanho e pela baixa porcentagem de polpa, como também por não apresentarem um equilíbrio satisfatório entre os seus elementos constitutivos. Mas as suas características relacionadas com vigor, resistência, produtividade, adaptação às regióes onde uniformemente há umidade e a temperatura é elevada, nos mostram claramente o importante papel que terão de desempenhar na criação de novos tipos de videira para as regiões mais quentes do Brasil, abrangendo até mesmo o Pará e o Aznazonas, que se acham na zona equatorial.

Em nossos trabalhos em Campinas, temos observado que o grupo das videiras tropicais se cruza com facilidade com as vinfferas.

Em Costa-Rica, Fennell (8) efetuou grande número de interessantes cruzamentos entre as espécies tropicais e viniferas, obtendo novas formas bastante melhoradas, já na primeira geração.

O material com que estamos trabalhando é originário do Iustitnto Inter-Americano de Ciências Agrícolas de Turrialba, Costa Rica, e consta das seguintes castas: 


\section{VITIS TILIAEFOLIA, $\mathrm{H} \& \mathrm{~B}$ \\ VITIS SHUTTLEWORTHII, HOUSE \\ VITIS GIGAS, FENNELL \\ VITIS SIMPSONI, MUNSON \\ VITIS RUFO TOMENTOSA, SMALL}

A primeira está incluída no grupo CARIBAEA. A segunda se acha no grupo LABRUSCOIDEAE, segundo Bailey (2). As outras três fazem parte do grupo AESTIVALIS, ainda conforme Bailey (2).

Tôdas elas, em Campinas, estão apresentando desenvolvimento vegetativo enorme, muito superior às outras variedades que se acham em cultura, e com boa produção de frutos, bem formados, resistentes aos estragos das chuvas e às podridões (estampa $4-A, B, C$ ).

Os cruzamentos foram efetuados com as seguintes castas :

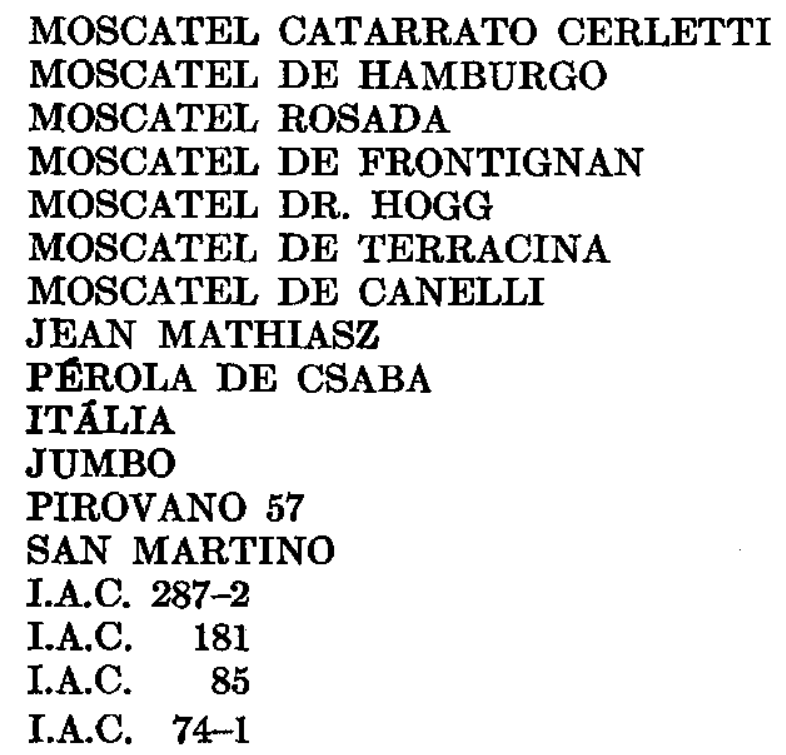

Em nosso campo de híbridos existem já algumas centenas de plantas em observação, provenientes de combinações entre as espécies tropicais, as viníferas mencionadas e novas variedades I.A.C., com desenvolvimento vigoroso e sadías, e esperamos, no futuro, poder apresentar novas variedades com aptidбes para produzir econômicamente fruta de boa qualidade nas regióes brasileiras de clima tropical e equatorial.

\section{4 - RESULTADOS}

As novas variedades que, em seguida, vamos mencionar, estão em cultivo nos lotes semi-comerciais da Seção de Viticultura do Instituto Agronômico de Campinas, bem como em outras propriedades particulares no interior do Estado de São Paulo, onde vêm se comportando satisfatòriamente. Não é possível garantir que o mesmo se dê em tôdas as regióes e situações, em vista das mudanças de ambiente que, em certas localidades, poderão ser impróprias, desfavoráveis, e impedir que elas prosperem, como se deseja. 


\section{I.A.C. 181}

Progenitores : Moscatel rosada x Dutchess

Cồ : Branca

Sabôr : Moscatel

Cacho: Grande - solto

Baga: Grande - carnosa

Maturação: Precose, 1. quinzena de Dezembro - Janeiro

Resistência a moléstias e pragas: Grande

Açúcar : $16,5 \%$ do mosto

Acidês $\%: 11,2$ ce $\mathrm{NaOH} \mathbf{n} / 10$

E uma das melhores entre as novas variedades de mesa obtidas (estampa 5 - A). Vegetativamente apresenta em gráu elevado os caractéres das castas americanas, produtiva, vigorosa, com boa adatação ao nosso ambiente, perfeita e completa maturação dos frutos e do lenho dos ramos, grande resistência às moléstias mais comuns entre nós.

Possui o sabôr moscatel acentuado e peculiar ao progenitor feminino. Mantém-se na planta sem apodrecer e sem estragar durante bom espaço de tempo, antes de ser colhida. Cacho solto. Frutos com grande aderência ao pedicele.

Nos últimos dois anos tem sido utilizada para novas combinações, mas com alguma dificuldade quanto à conservação e emprêgo do seu pólen.

\section{I.A.C. $274-16$}

Progenitores: Seibel $11.342 \times$ Perlona

Côr : Branca

Sabôr : Franco

Cacho : Médio - denso

Baga: Média - fundente

Maturação : 2. ${ }^{\mathrm{a}}$ quinzena de Janeiro - Fevereiro

Resistência a moléstias e pragas : Grande

Açúcar : $20,5 \%$ do mosto

Acidês \%: 14,2 cc de $\mathrm{NaOH} \mathrm{n} / 10$

Variedade de boa aparência (estampa $5-B$ ), sabôr franco vivo, agradável, produtiva, resistente, com boas características de adaptação. Frutos e ramos uniformemente bem maduros. Cachos médios, bem formados, que se conservam na planta sem apodrecer.

\section{I.A.C. $164-20$}

Progenitores : Niágara Rosada x Moscatel rosada

Côr : Preta

Sabôr : Franco 
Cacho : Grande, bem solto

Baga: Média, meio carnosa

Maturação: Média, fins de Janeiro até princípios de Março

Resistência a moléstias e pragas : Grande

Açúcar : $16,5 \%$ do mosto

Acidês $\%: 13,0$ cc de $\mathrm{NaOH} \mathrm{n} / 10$

Apresenta grande semelhança ao seu progenitor feminino quanto à sua vegetação, resistência, produtividade, boa adaptação ao nosso ambiente. Os cachos são maiores, (estampa $6-A$ ), bem soltos, e os frutos com sabôr franco, agradável, sem o menor indício que faça lembrar o "foxado" característico da Niágara. Conservam-se os cachos na planta por bastante tempo, sem o mínimo estrago e livres de podridões.

Pelas suas boas características provàvelmente constituir-se-á em uma casta de dupla finalidade, para mesa e para vinho.

Nos últimos dois anos vem sendo usada em novas combinaçбes pela Seção de Viticultura.

\section{I.A.C. $116-31$}

Progenitores: Seibel $7.053 \times$ Pinot noir

Côr : Branca

Sabôr : Franco

Cacho : Grande

Baga : Média

Maturação : Janeiro

Resistêncía a moléstias e pragas : Grande

Açúcar : $19,75 \%$ do mosto

Acidês $\%: 12,5$ cc de $\mathrm{NaOH} \mathbf{n} / 10$

Variedade muito sadía, apresentando grande desenvolvimento, resistência, adaptação muito boa ao nosso ambiente, fornecedora de abundante produção de frutos (estampa $6-B$ ), que tem sido transformada em vinho de muito boa qualidade, o qual, segundo a opinião abalizada do Dr. P. H. Raffour, pode ser equiparado aos tipos brancos BORDEAUX.

\section{I.A.C. $287-2$}

Progenitores : Niágara Rosada x Jumbo

Côr : Rosada

Sabôr : Franco - simples

Cacho: Médio

Baga: Média

Maturação : Fevereiro

Resistência a moléstias e pragas : $\mathrm{Boa}$

Açúcar : $12,5 \%$ do mosto

Acidês $\%: 12,4$ cc de $\mathrm{NaOH}$ n/10 
E a única variedade nova apirena, obtida, que atinge completa maturação dos frutos sem apresentar estragos ou apodrecimento. Tem resistido bem às chuvas pesadas, às vêzes repetidas amiudadamente, mantendo-se em excelentes condições até a colheita, nas localidades de Vinhedo e Mogi das Cruzes.

Sua vegetação possui características muito próximas do progenitor feminino - Niágara rosada - , sendo resistente, vigorosa, com perfeita maturação do lenho dos ramos.

A frutificação (estampa $7-A$ ) e sobretudo a ausência de sementes, tamanho dos frutos, conformação do cacho, se assemelham ao progenitor masculino Jumbo.

I.A.C. 21-5

Progenitores : Seibel 11.342 x Moscatel de Canelli

Côr : Branca

Sabôr : Franco

Cacho: Grande - Solto

Baga: Quase média

Maturação : Janeiro

Resistência a moléstias e pragas: Grande :

Açúcar : $19,75 \%$ do mosto

Acidês $\%: 12,5$ ce de $\mathrm{NaOH} \mathrm{n} / 10$

Variedade de grande produção de frutos (estampa $7-B$ ), que se conservam durante muito tempo na planta sem se estragar nem apodrecer, atingindo uma completa maturação, o que é de grande vantagem para a obtenção de bom vinho. E resistente e possuidora de boas características de adaptação ao nosso ambiente.

\section{I.A.C. $74-1$}

Progenitores: Seibel 10.096 x Syrah

Côr : Branca

Sabôr : Franco característico

Cacho: Enorme

Baga : Média

Maturação: Janeiro

Resistência a moléstias e pragas : Grande

Açúcar : $18,00 \%$ do mosto

Acidês $\%: 12,0$ cc de $\mathrm{NaOH} \mathrm{n} / 10$

Entre as variedades brancas destinadas à produção de vinho esta é a que reune maior número de bons predicados. Boa adaptação às nossas condições ambientes, grande produção de cachos enormes (estampa $7-C$ ) todos os anos, perfeita maturação dos frutos e do lenho dos ramos. $O$ vinho que 
fornece é de alta qualidade, na opinião de diversos degustadores, e, segundo o Dr. P. H. Raffour pode ser enquadrado no tipo Pouilly Fuissé, um dos grandes vinhos brancos franceses.

No município de Atibaia, São Paulo, esta variedade vem sendo cultivads já há quatro anos, em condiçzes satisfatórias e muito animadoras.

\section{I.A.C. 192-53}

Progenitores: Seibel 8.712 x Moscatel de Hamburgo

Côr : Preta

Sabôr : Franco típico

Cacho: Muito grande

Baga : Média

Maturação: Fevereiro

Resistência a moléstias e pragas : Grande

Agúcar : 20,00\% do mosto

Acidês $\%: 16$ cc de $\mathrm{NaOH} \mathrm{n} / 10$

Variedade produtora de lindos cachos grandes (estampa $8-A$ ), que se conservam em perfeito estado na planta até a ocasião da colheita.

Sua produção tem sido grande, e as suas características se assemelham muito de perto às das castas viniferas.

\section{I.A.C. 74-2}

Progenitores : Seibel $10.096 \times$ Syrah

Cốr : Preta

Sabôr : Franco

Cacho: Enorme

Baga: Média

Maturação: Fins de Janeiro a Fevereiro

Resistência a moléstias e pragas: Grande

Açúcar : $19 \%$ do mosto

Acidês $\%: 12,25$ cc de $\mathrm{NaOH} \mathrm{n} / 10$

Apresenta-se esta variedade com cachos volumosos (estampa $8-B$ ), em abundância, fornecendo grande produção. E sadía e vigorosa. Fornece um vinho de boas características para mesa, muito superior ao do seu progenitor feminino, sob vários aspetos.

$$
\text { I.A.C. } 80-8
$$

Progenitores: Seibel $13.053 \times$ Pinot noir

Côr : Preta

Sabôr : Franco

Cacho: Médio, denso 
Baga : Média

Maturação : Janeiro

Resistência a moléstias e pragas : Muito grande

Açúcar : $20,0 \%$ do mosto

Acidês \%: 15 cc de $\mathrm{NaOH}$ n/10

Esta variedade (estampa $9-A$ ) se distingue pela sua grande rusticidade, característica que é peculiar ao seu progenitor feminino, grande desenvolvimento vegetativo e saúde.

Fornece um vinho acentuadamente colorido, macio, equilibrado, bom cheiro e bom corpo.

\section{I.A.C. $36-5$}

Progenitores: Seibel $7.162 \times$ Moscatel rosada

Côr : Preta

Sabôr : Moscatel

Cacho: Grande

Baga: Média

Maturação: Janeiro - Fevereiro

Resistência a moléstias e pragas : Grande

Açúcar : $16 \%$ do mosto

Acidês $\%: 12$ cc de $\mathrm{NaOH} \mathrm{n} / 10$

Variedade produtiva (estampa $9-B$ ), apresentando-se como das melhores entre as de sabor moscatel e pretas. Presta-se para a produção de bons vinhos aromáticos de diferentes tipos, grandemente apreciados entre nós.

\section{I.A.C. $193-1$}

Progenitores: Seibel 8.712 x Moscatel rosada

Côr : Branca

Sabôr : Moscatel

Cacho: Grande

Baga : Média

Maturação : Fins de Janeiro

Resistência a moléstias e pragas : Grande

Açúcar : $18,5 \%$ do mosto

Acidês $\%: 12$ ce de $\mathrm{NaOH} \mathbf{n} / 10$

Distingue-se pela sua rusticidade, vigor e produtividade. Cachos grandes (estampa 9-C), com sabor moscatel forte, prestando-se para a produção de vinhos brancos de aroma moscatel, muito procurados e de grande aceitação entre nós. 


\section{GRAPE BREEDING IN BRAZIL}

\section{SUMMARY}

Grape breeding. was first started in Brazil by Pereira Barreto in 1895. From 1930 to 1940, Paulino Recch, Nicolau Martorano, and Pedro Araujo, from Amparo, São Paulo, did some breeding work with grapes and obtained several new types that proved valuable. In the Instituto Agronomico de Campinas, grape breeding work was initiated in 1943 by the Section of Viticulture.

The grape breeding program of the Section of Viticulture aimed at obtaining improved varieties for rootstocks, for fresh fruit and raisin consumption, and also for the making of wines and juice. Besides the specific qualities required for each different use, the types to be selected had to be well adapted to local environmental conditions, present resistance to insect pests and diseases, and also be resistant to handling and shipping.

The basic material used in the improvement program consisted of the collection of grape varieties of the Instituto Agronômico that included many European and American standard varieties, supplemented by new and wild types imported from North and Central America. In this program special attention is being given to the production of seedless types and to hybrids between standard European and American varieties and the wild species, Vitis gigas and V. tilixfolia.

Results already obtained are very encouraging and indicated that some of the new types are very good as rootstocks, whereas others are excellent for table uses or for wine or juice making.

\section{LITERATURA CITADA}

1. AMERINE, M. A. \& WINKLER, A. J. Composition and quality of musts and wines of California grapes. Hilgardia $15:[493]-673.1944$.

2. BAILEY, L. H. The species of grapes peculiar to North America. Gentes Herb., Ithaca $3: 151-244.1934$.

3. CARPENTIERI, F. Trattato di viticoltura. In Ottavi, Ottavio, ed. Viticoltura teorico pratica, 5." ed. Casale Monf., Ottavi, 1929-30. 2v.

4. CAVAzZA, DoMizIO. Viticoltura. 2." ed. Torino, Unione Tipografico, 1934. 814 p.

5. CONGRÈS INTERNATIONAL DE LA VIGNE ET DU VIN. Vème, Lishoa, 1938. Rapports. III - L'organisation viti-vinicole dans les différents pays au point de vue de la defense de la production. Lisboa, s.c.p., 1938. 227 p.

6. CouTinho, M. C. P. Doenças e pragas da videira. Lisboa, Sá da Costa, 1945. $190 \mathrm{p}$.

7. Dalmasso, G. Problemi di viticoltura moderna. Milano, C. E. A., s. d. 282 p.

8. FENNEL, J. L. Inheritance studies with the tropical grape. Costa Rica, Inter-American Institute of agricultural Science, 1948. [11 p.] (Techn. Publ. n.* 23)

9. LONGO, A. Viticoltura per le uve da tavola con riferimento anche ai sistemi colturale per le uve da vino. Roma, Ramo editoriale degli agricoltori, 1948. (Trattati di agricoltura, V. 7).

10. MANARESI, A. Trattato di viticoltura. 2.a ed., Bologna, s.c. p., 1947. vi; 624 p.

11. MUNSON, T. V. Foundations of American grape culture. New York, Orange Judd, 1909.252 p.

12. OLMO, H. P. Perlette and Delight two new early maturing seedless table grape varieties. Berkeley, University of California, 1948. [8 p.] (Bull. n. ${ }^{\circ}$ 705) 
13. - Ruby Cabernet and Emerald Riesling two new tablewine grape varieties. Berkeley, University of California, 1948. [12 p.] (Bull. n.* 704)

14. —_ Scarlet a new grape variety for fresh juice and jellies. Berkeley, University of California, 1948. [6 p.] (Bull. n. ${ }^{\circ}$ 706)

15. PAZ, C. Manual nratico do viticultor brasileiro. Rio de Janeiro, Imprensa nacional, 1908. xxviii, 151 p.

16. PEROLD, A. I. A treatise on viticulture. London, Macmillan, 1927. xi, $696 \mathrm{p}$.

17. RAVAZ, L. Les vignes americaines : porte-greffes et producteurs directes ; caractères-aptitudes. Montepellier, Coulet \& Fils. '1902. vii, 376 p.

18. STOUT, A. B. Seedlessness in grape. New York, Agricultural expcriment Station, 1936. [68 p.] (Techn. Bull. 1.. 238) 


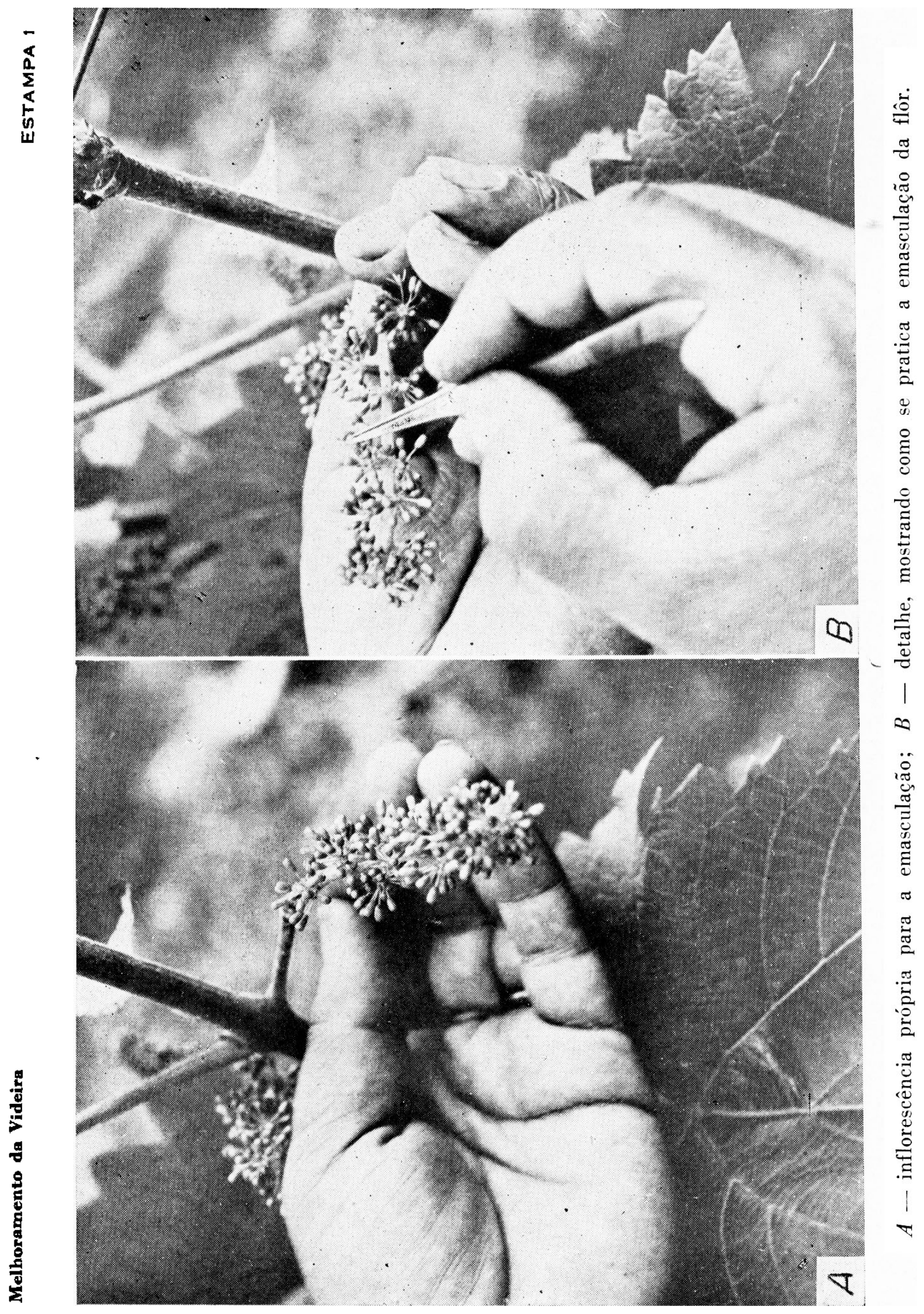




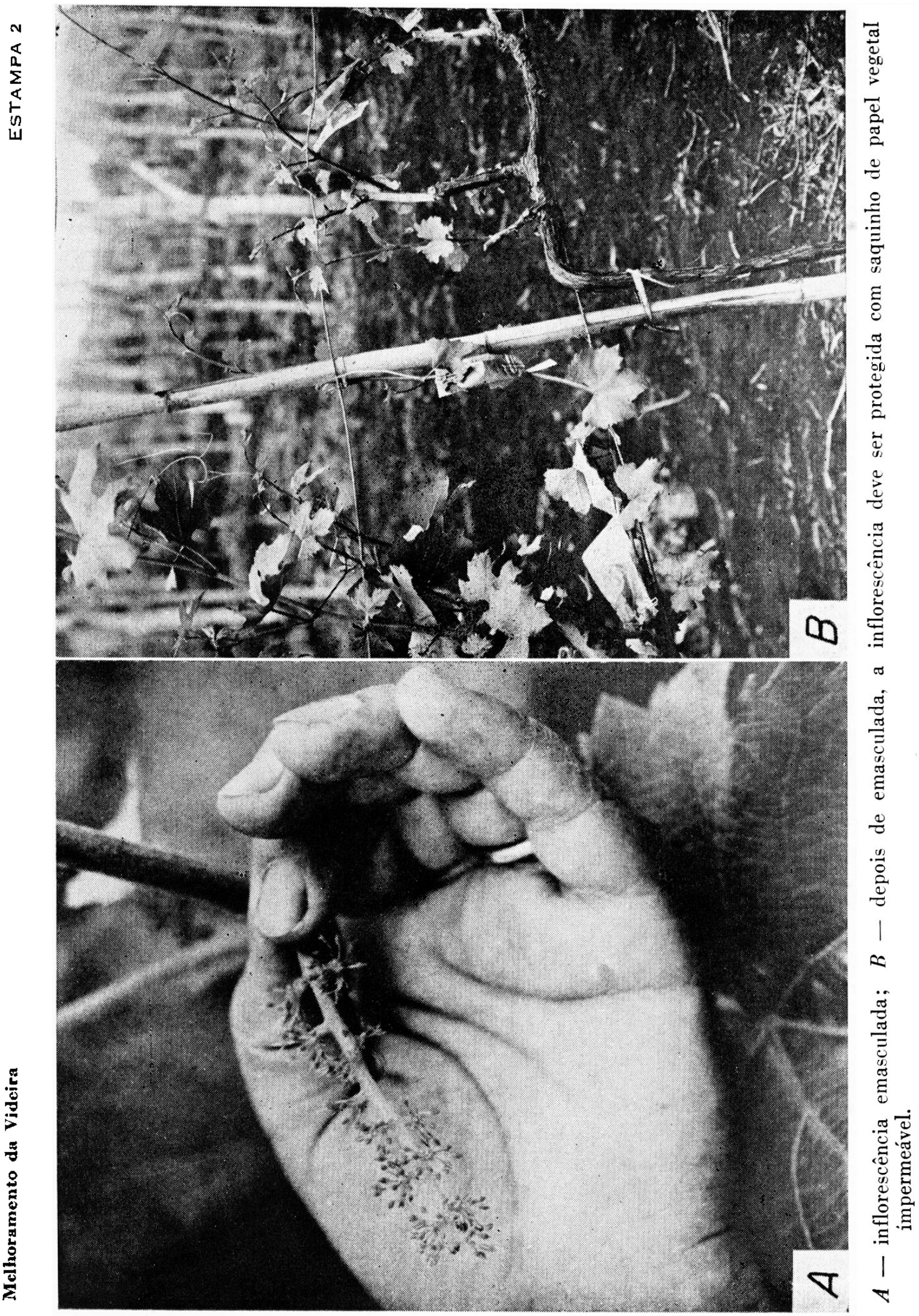




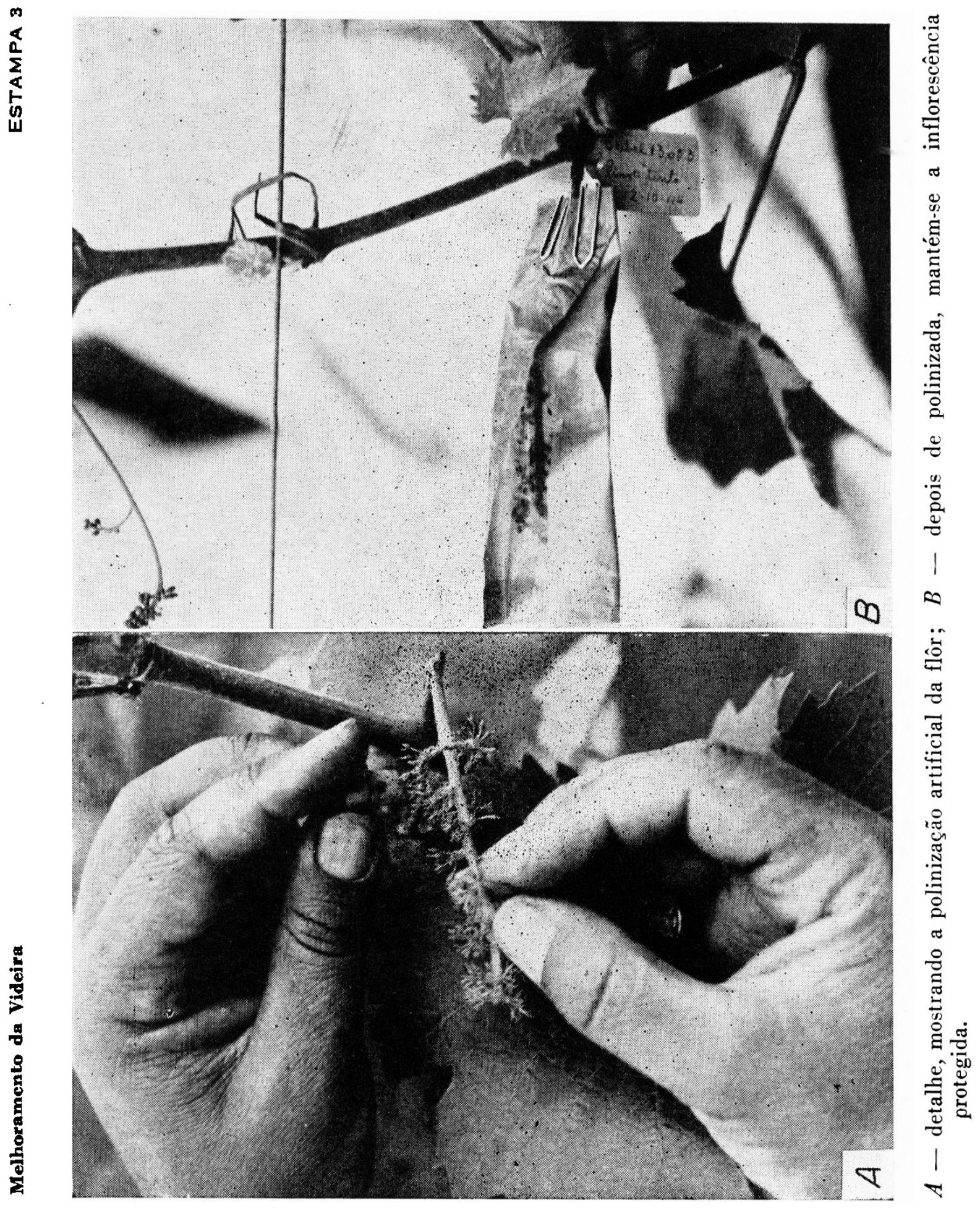



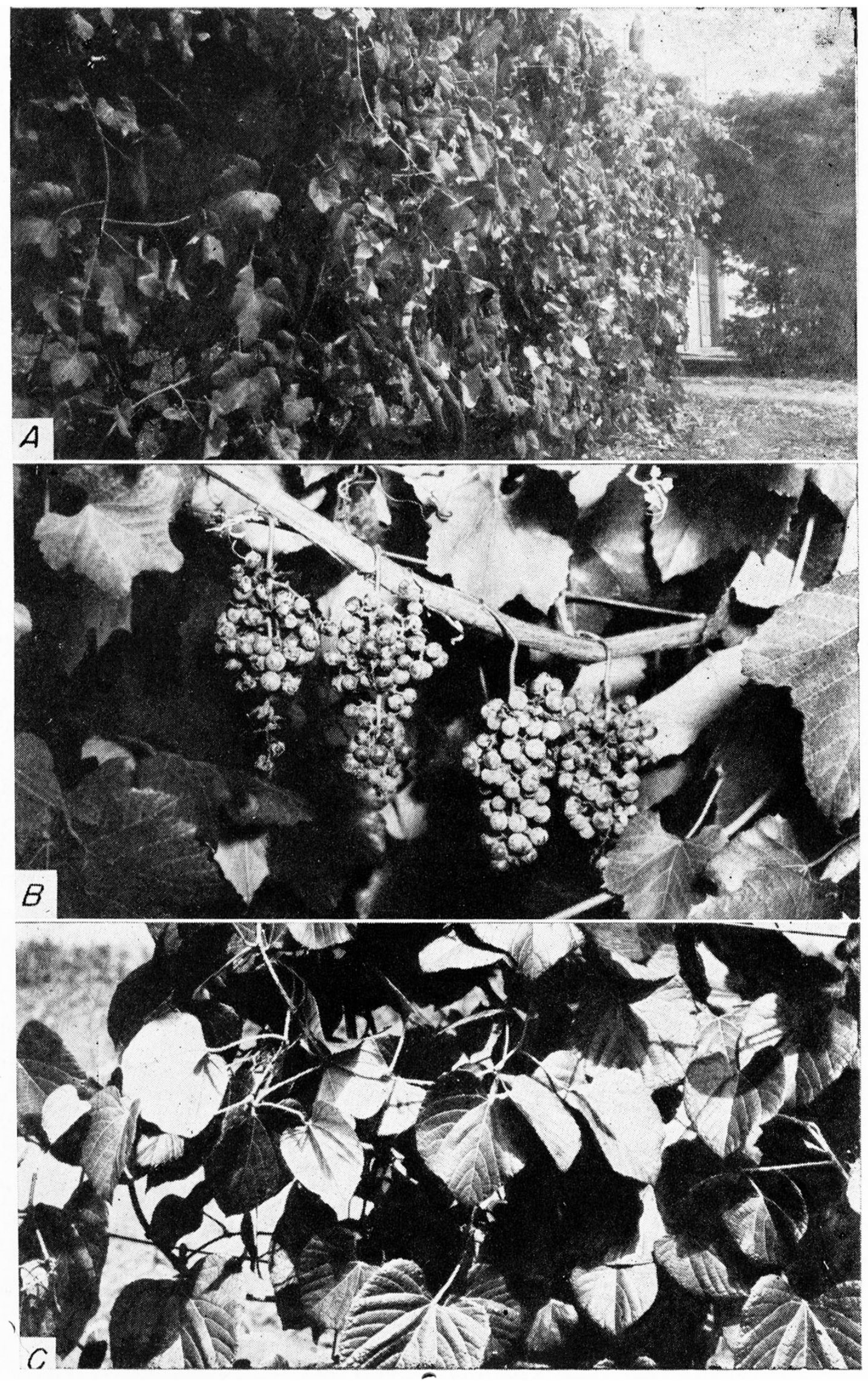

$A$ e $B$-Vitis gigas Fennel; $C$ - tiliaefolia H. \& B.; vinhedo da Seção de Viticultura, na Estação Experimental Central do Instituto Agronômico. 

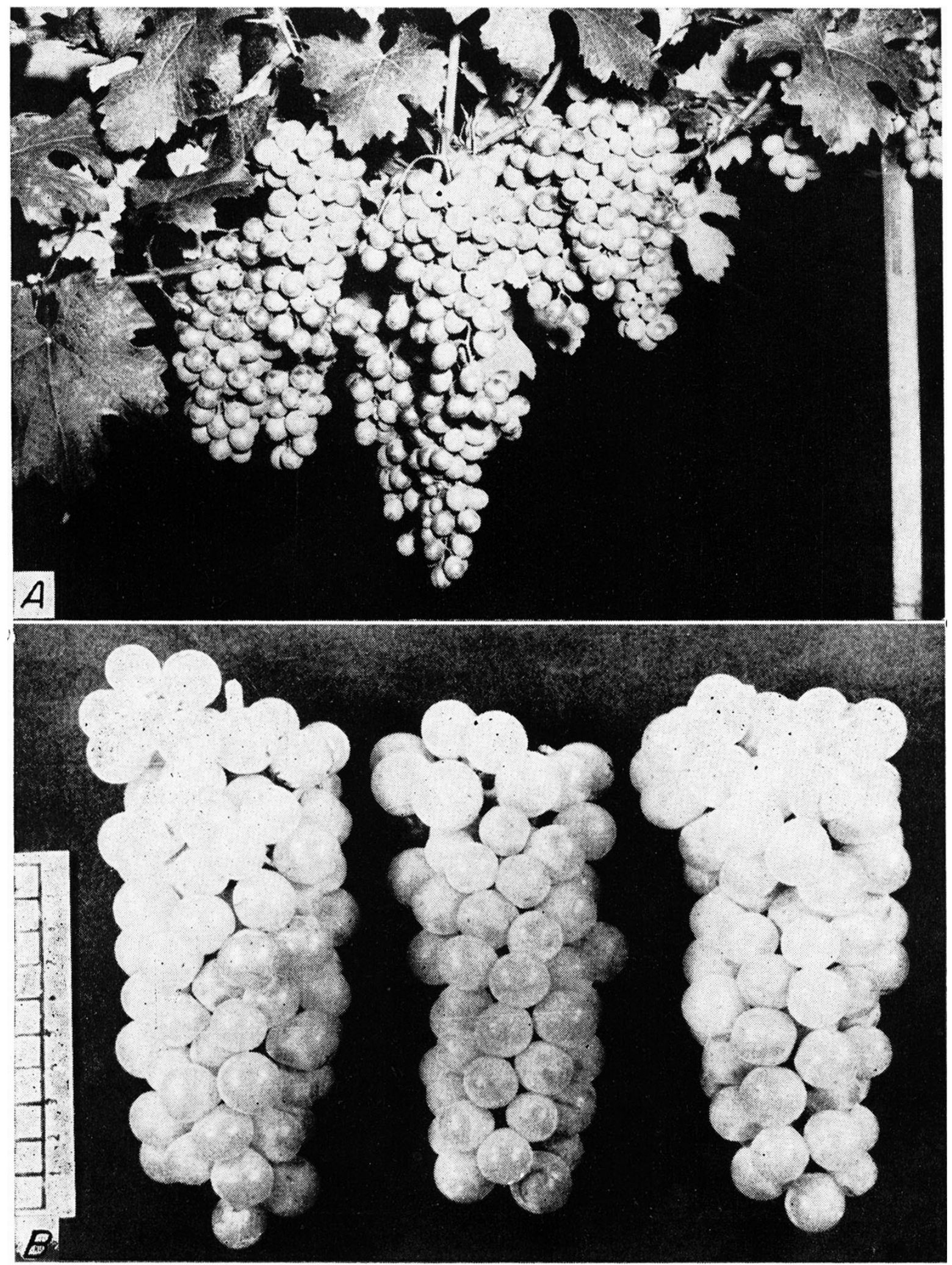

A - híbrido I.A.C. 181 (Moscatel rosada x Dutchess); $B$ - híbrido I.A.C. 274-16 (Seibel 11.342 x Perlona). 


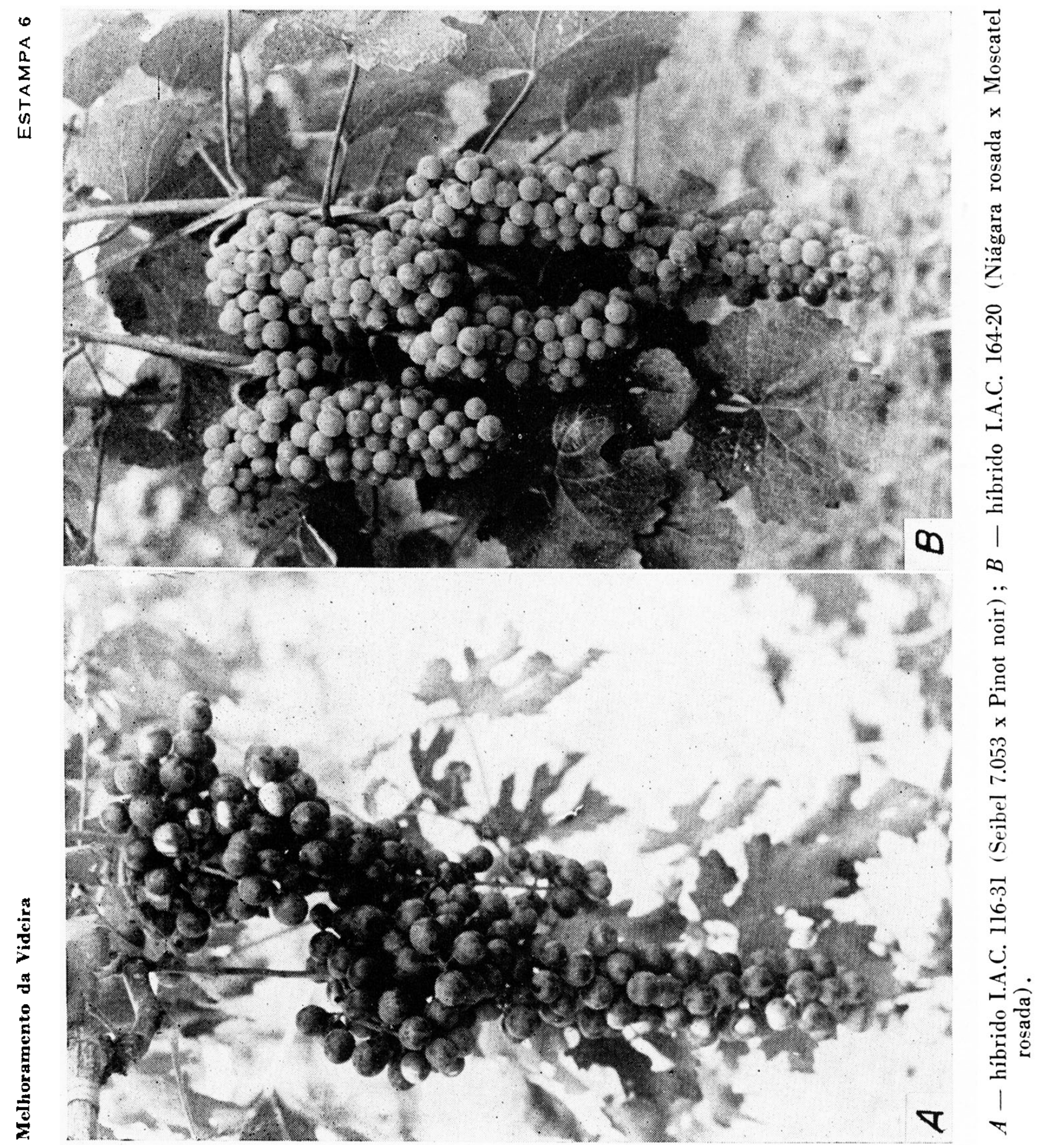



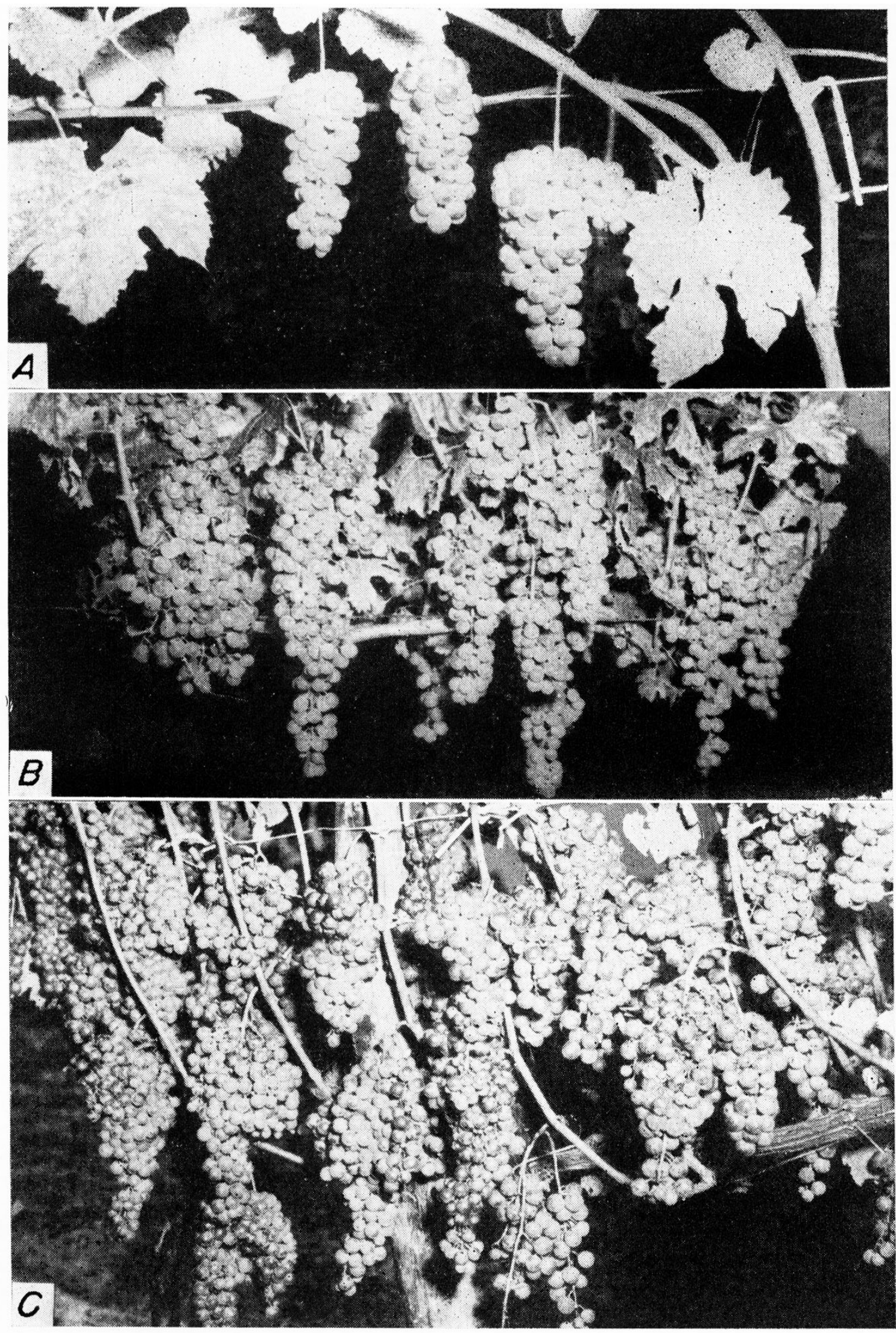

$A$ - híbrido I.A.C. 287-2 (Niágara rosada x Jumbo) ; $B$ - híbrido I.A.C. 21-5 (Seibel 11.342 x Moscatel de Canelli); $C$ - híbrido I.A.C. 74-1 (Seibel 10.096 x Syrah). 


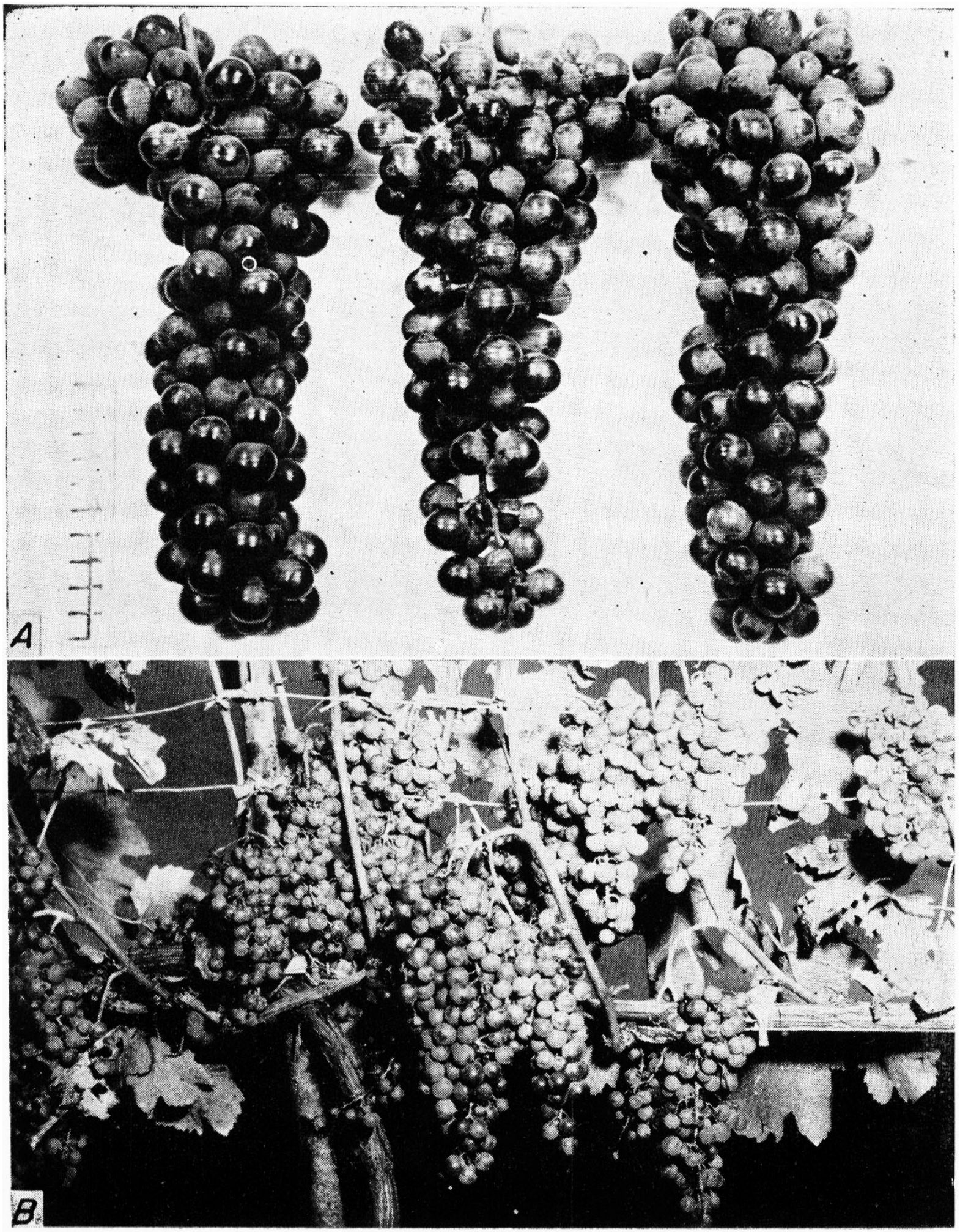

$A$ - híbrido I.A.C. 192-53 (Seibel 8.712 x Moscatel de Hamburgo) ; $B$ - híbrido I.A.C. 74-2 (Seibel 10.096 x Syrah). 


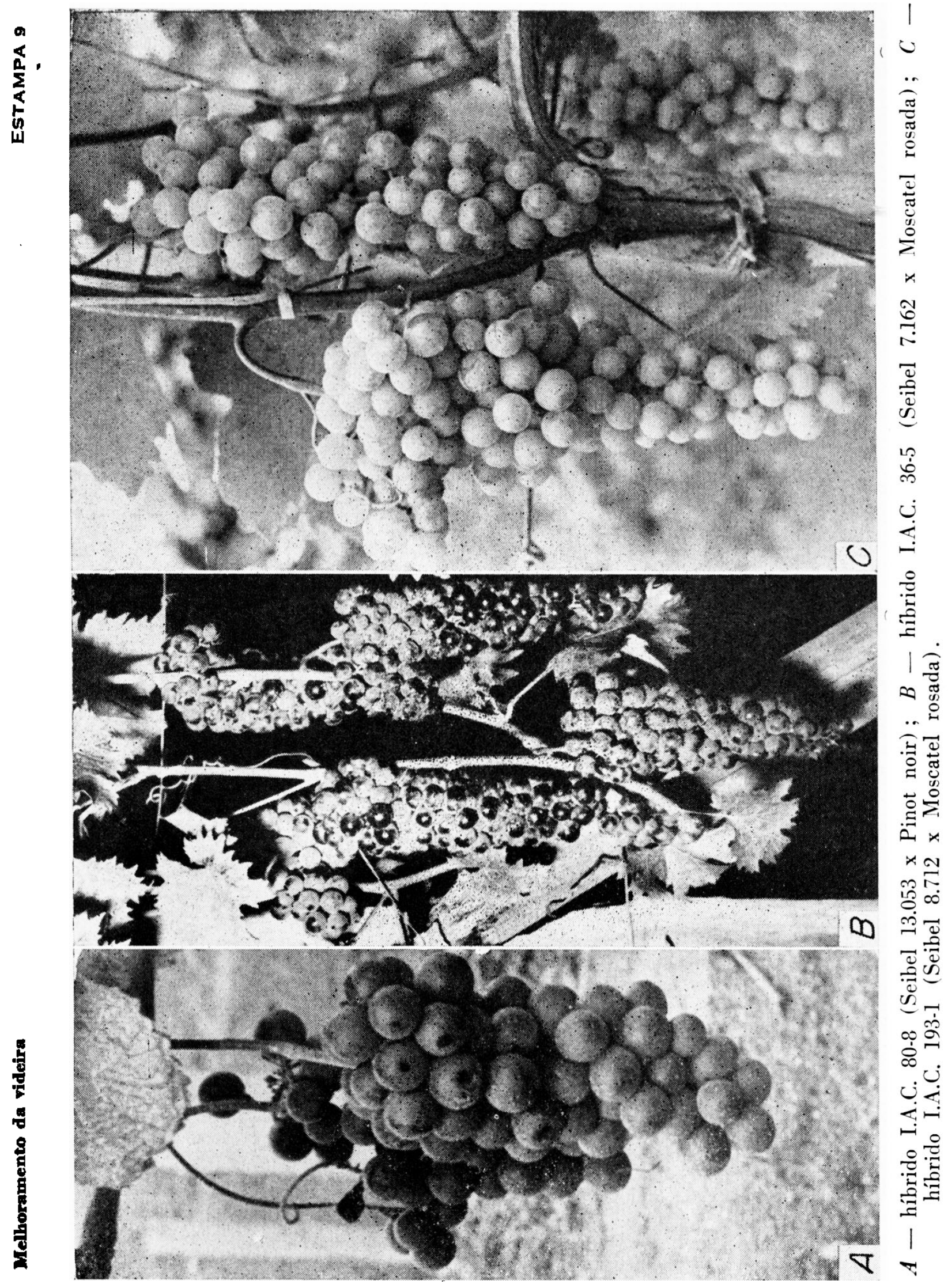

